\title{
EFEKTIVITAS KEGIATAN KELOMPOK KERJA GURU (KKG)
} AGAMA HINDU MELALUI TEKNIK UMPAN BALIK

\author{
Oleh: \\ Dewa Agung Putri Widiasih \\ Kantor Kementerian Agama Kabupaten Gianyar \\ e-mail: dewaagungputriwidiasih@yahoo.co.id
}

\begin{abstract}
The act No. 14 of 2005, article 1, paragraph 1 states that the teachers are professional educators with the primary task of educating, teaching, guiding, directing, training, assessing and evaluating the students on the early childhood education, formal education, primary education, and middle education. The teachers are required to carry out the process of learning which includes exploration, elaboration and confirmation to change the educational paradigm, which is from the paradigm of teaching to the paradigm learning. The obstacle for the teachers is that because they have abandoned the strategy of teacher-centered learning (teacher center oriented) strategies in order to work on the studentcentered learning orientation.
\end{abstract}

Keywords: Effectivity, Working Group, Hindu Religion Teachers

\begin{abstract}
Abstrak
Undang-Undang RI Nomor 14 tahun 2005, pasal 1 ayat 1 disebutkan bahwa guru adalah pendidik profesional dengan tugas utama mendidik, mengajar, membimbing, mengarahkan, melatih, menilai dan mengevaluasi peserta didik pada pendidikan anak usia dini jalur pendidikan formal, pendidikan dasar, dan pendidikan menengah. Guru diwajibkan untuk melaksanakan pembelajaran yang meliputi proses eksplorasi, elaborasi dan konfirmasi untuk mengubah paradigma pendidikan yaitu dari paradigma pengajaran ke paradigma pembelajaran. Sebuah kendala bagi guru, karena harus meninggalkan strategi pembelajaran yang berpusat pada guru (teacher centre oriented) ke strategi pembelajaran yang berpusat pada siswa (student centre oriented).
\end{abstract}

Kata kunci: Efektivitas, Kelompok Kerja, Guru Agama Hindu

\section{PENDAHULUAN}

Guru di Indonesia hendaknya menyadari bahwa tugas yang diembannya merupakan jabatan profesi yang keberadaannya tidak dapat tergantikan oleh orang lain walaupun bersal dari profesi yang sama. Oleh karena itu guru memiliki tugas yang sangat mulia dalam mencerdaskan anak bangsa serta mampu melahirkan generasi bangsa yang beriman, bertakwa, dan berahlak mulia, serta menguasai ilmu pengeta- huan dan seni keagamaan Hindu.

Undang-Undang RI Nomor 14 tahun 2005, pasal 1 ayat 1 disebutkan bahwa guru adalah pendidik profesional dengan tugas utama mendidik, mengajar, membimbing, mengarahkan, melatih, menilai dan mengevaluasi peserta didik pada pendidikan anak usia dini jalur pendidikan formal, pendidikan dasar, dan pendidikan menengah. Selanjutnya pada pasal 1 ayat 2 disebutkan profesional adalah pekerjaan atau kegiatan yang dilakukan oleh seseorang dan men- 
jadi sumber penghasilan kehidupan yang memerlukan keahlian, kemahiran atau kecakapan yang memenuhi standar mutu atau norma tertentu serta memerlukan pendidikan profesi.

Ahmad Rizal (2009:15) menyatakan bahwa guru masih melihat bidang studinya berupa "text" dan belum "context" karena metode CTL (Contextual teaching and learning) masih berupa wacana dan belum menjadi pengetahuan, apalagi keterampilan dan guru-guru tampaknya masih terjebak pada filosofi dan pendekatan yang melekat pada lingkungan belajarnya.

Hal ini yang menyebabkan kelayakan mengajar guru masih rendah, menurut Rizali (2009:22) data tahun 2000/2001 menunjukkan bahwa terdapat $49.49 \%$ guru SD yang layak jika mengacu pada kualifikasi mengajar minimal DII. Sedangkan, sebanyak 50,31\% yang dinilai tidak layak. Pada tingkat SMP, terdapat 66,33\% yang dinilai layak mengajar minimal DIII, sedangkan terdapat 33,67\% yang dinilai tidak layak.

Sedangkan menurut Sudarwan Danim (2011:vii) baik UU no. 14 Tahun 2005 tentang Guru dan Dosen maupun PP No. 74 Tahun 2008 tentang Guru secara tegas menyebutkan bahwa ketika seseorang berkualifikasi S-1/D-IV dan memiliki sertifikat pendidik, negara telah mengakuinya sebagai guru profesional. Guru yang ada di Indonesia kebanyakan masih kurang profesional dalam hal kualifikasi pendidikan minimal bagi seorang guru. Selanjutnya pemerintah juga masih mengeluarkan peraturan yang tumpang tindih sehingga memunculkan sebuah ketidak profesionalannya, guru yang profesional merupakan faktor penentu proses pendidikan yang bermutu

Penerapan Kurikulum 2013 memberikan warna tersendiri dalam dunia pendidikan di Indonesia. Konsep yang dikembangkan dalam kurikulum 2013 menekankan pada dimensi pedagogik modern dalam pembelajaran, yaitu menggunakan pendekatan ilmiah. Pendekatan ilmiah (scientific appoach) dalam pembelajaran sebagaimana dimaksud meliputi mengamati, menanya, menalar, mencoba, membentuk jejaring untuk semua mata pelajaran. Beranjak dari hal tersebut di atas guru dituntut untuk mampu memahami dan melaksanakan kurikulum 2013, sebagai mana yang diamanatkan oleh undangundang.

Realita yang terjadi dilapangan, khususnya di kecamatan Gianyar, sebagaian besar guru agama khususnya pada jenjang pendidikan dasar, belum memahami secara maksimal dalam menyusun instrumen penilaian sesuai dengan ketentuan yang dipersyaratkan oleh PP 19 Tahun 2005 tentang Standar Penilaian serta tuntutan kurikulum 2013. Oleh sebab itu wadah kegiatan yang bersifat kordinasi, serta bertukar fikiran seperti KKG (Kelompok Kerja Guru) sangat dibutuhkan keberdaanya, dan sampai saat ini merupakan salah satu alternatif dalam memecahkan berbagai permasalahan yang dihadapi guru. Beranjak dari hal tersebut di atas penulis mencoba mengkaji tentang "Efektivitas Kegiatan Kelompok Kerja Guru (KKG) Agama Hindu Melalui Teknik Umpan Balik Dalam Meningkatkan Kompotensi Guru Menyusun Instrument Penilaian Sesuai Kurikulum 2013 di Kecamatan Gianyar, Kabupaten Gianyar Tahun Pelajaran 2013/2014". Masalah-masalah pokok dalam penelitian ini adalah: 1) Apakah Kegiatan KKG dapat meningkatkan komitmen guru-guru agama Hindu di Kecamatan Gianyar Kabupaten Gianyar dalam menyusun Instrumen Penilaian sesuai dengan tuntutan kurikulum 2013? 2) Apakah kegiatan KKG dapat meningkatkan kemampuan guru-guru agama Hindu di Kecamatan Gianyar Kabupaten Gianyar dalam menyusun Instrumen Penilaian sesuai dengan tuntutan kurikulum 2013

\section{PEMBAHASAN}

\subsection{Tentang Penilaian}

\subsubsection{Definisi Penilaian}

Peraturan pemerintah nomor 19 tahun 2005, tentang Standar Pendidikan Nasional Bab 1, pasal 1 memberikan definisi terhadap penilaian sebagai proses pengumpulan dan pengolahan informasi untuk mengetahui tingkat ketercapaian dan peningkatan kemampuan peserta didik. Penilaian hasil belajar oleh guru dilakukan secara berkesinambungan, bertujuan untuk memantau proses dan kemajuan belajar peserta didik serta untuk meningkatkan efektivitas kegiatan pembelajaran. Penilaian tersebut meliputi kegiatan, sebagai berikut:

1. Menginformasikan silabus mata pelajaran yang di dalamnya memuat rancangan dan kriteria penilaian pada awal semester. 
2. Mengembangkan indikator pencapaian KD dan memilih teknik penilaian yang sesuai pada saat menyusun silabus mata pelajaran.

3. Mengembangkan instrumen dan pedoman penilaian sesuai dengan bentuk dan teknik penilaian yang dipilih.

4. Melaksanakan tes, pengamatan, penugasan, dan/atau bentuk lain yang diperlukan.

5. Mengolah hasil penilaian untuk mengetahui kemajuan hasil belajar dan kesulitan belajar peserta didik.

6. Mengembalikan hasil pemeriksaan pekerjaan peserta didik disertai balikan/ komentar yang mendidik.

7. Memanfaatkan hasil penilaian untuk perbaikan pembelajaran.

8. Melaporkan hasil penilaian mata pelajaran pada setiap akhir semester kepada pimpinan satuan pendidikan dalam bentuk satu nilai prestasi belajar peserta didik disertai deskripsi singkat sebagai cerminan kompetensi utuh.

9. Melaporkan hasil penilaian akhlak kepada guru pendidikan agama dan hasil penilaian kepribadian kepada guru pendidikan kewarganegaraan sebagai informasi untuk menentukan nilai akhir semester akhlak dan kepribadian peserta didik dengan kategori sangat baik, baik, atau kurang baik

\subsubsection{Fungsi Penilaian}

Secara umum fungsi penilaian meliputi beberapa hal sebagai berikut:

1. Menggambarkan sejauh mana seorang peserta didik telah menguasai suatu kompetensi.

2. Mengevaluasi hasil belajar peserta didik dalam rangka membantu peserta didik memahami dirinya, membuat keputusan tentang langkah berikutnya, baik untuk pemilihan program, pengembangankepribadian, maupun untuk penjurusan (sebagai bimbingan).

3. Menemukan kesulitan belajar dan kemungkinan prestasi yang bisa dikembangkan peserta didik dan sebagai alat diagnosis yang membantu guru menentukan apakah seseorang perlu mengikutiremedial atau pengayaan.
4. Menemukan kelemahan dan kekurangan proses pembelajaran yang sedang berlangsung guna perbaikan proses pembelajaran berikutnya.

5. Sebagai kontrol bagi guru dan sekolah tentang kemajuan perkembangan peserta didik.

\subsubsection{Manfaat Penilaian}

Pada Hakekatnya manfaat penilaian meliputi beberapa hal sebagai berikut:

1. Memberikan umpan balik bagi peserta didik agar mengetahui kekuatan dan kelemahannya dalam proses pencapaian kompetensi.

2. Memantau kemajuan dan mendiagnosis kesulitan belajar yang dialami peserta didik sehingga dapat dilakukan pengayaan dan remedial.

3. Berbagai umpan balik bagi guru dalam memperbaiki metode, pendekatan, kegiatan, dan sumber belajar yang digunakan.

4. Masukan bagi guru guna merancang kegiatan belajar.

5. Memberikan informasi kepada orangtua dan komite sekolah tentang efektivitas pendidikan, dan

6. Memberi umpan balik bagi pengambil kebijakan dalam mempertimbangkan konsep penilaian kelas yang baik digunakan.

\subsubsection{Jenis Penilaian}

\section{Tes Tertulis}

Tes tertulis adalah suatu teknik penilaian yang menuntut jawaban secara tertulis, baik berupa obyekyif (pilihan ganda, menjodohkan, benar-salah, menjodohkan, melengkapi, mengisi) maupun uraian/essy. Dalam menyusun instrumen penilaian tertulis perlu dipertimbangkan hal-hal berikut.

a. Karakteristik mata pelajaran dan keluasan ruang lingkup materi yang akan diuji.

b. Materi, misalnya kesesuaian soal dengan Kompentensi Inti, Kompetensi Dasar dan Indikator pencapaian pada kurikulum.

c. Konstruksi, misalnya rumusan soal atau pertanyaan harus jelas dan tegas.

d. Bahasa, misalnya rumusan soal tidak menggunakan kata atau kalimat yang 
menimbulkan penafsiran ganda.

\section{Tes Lisan}

\section{Penilaian Sikap}

Sikap terdiri dari tiga komponen, yakni afektif, kognitif, dan konatif.Secara umum, objek sikap yang perlu dinilai dalam proses pembelajaran adalah, sebagai berikut:

a. Sikap terhadap materi pelajaran;

b. Sikap terhadap guru/pengajar;

c. Sikap terhadap proses pembelajaran;

d. Sikap berkaitan dengan nilai atau norma yang berhubungan dengan suatu materi pelajaran; dan

e. Sikap berhubungan dengan kompetensi afektif lintas kurikulum yang relevan dengan mata pelajaran.

\section{Observasi}

Guru dapat melakukan observasi secara langsung terhadap peserta didik yang dibinanya. Hasil pengamatan yang diperoleh dapat dijadikan sebagai umpan balik bagi peserta didik dalam pembinaan. Observasi perilaku di sekolah dapat dilakukan dengan menggunakan buku catatan khusus tentang kejadian-kejadian berkaitan dengan peserta didik selama di sekolah. Berikut contoh format buku catatan harian.

No. Hari/Tanggal :

Nama Peserta Didik :

Kejadian

Pada baris kejadian diisi dengan kejadian positif maupun negatif yang terjadi selama proses pengamatan.

\section{Tes Pertanyaan Langsung}

Peserta didik dan guru dapat menanyakan secara langsung atau melakukan wawancara tentang sikap seseorang berkaitan dengan sesuatu hal. Misalnya, bagaimana tanggapan peserta didik tentang kebijakan yang baru diberlakukan di sekolah mengenai "Peningkatan Ketertiban". Berdasarkan jawaban dan reaksi lain yang tampil dalam memberi jawaban dapat dipahami sikap peserta didik itu terhadap objek sikap. Dalam penilaian sikap peserta didik di sekolah, guru juga dapat menggunakan teknik ini dalam menilai sikap dan membina peserta didik.

\section{Laporan Pribadi}

Melalui penggunaan teknik ini di sekolah, peserta didik diminta membuat ulasan yang berisi pandangan atau tanggapan tentang suatu masalah, keadaan, atau hal yang menjadi objek sikap. Misalnya, peserta didik diminta menulis pandangannya tentang "Mengapa terdapat manusia terlahir cacat". Dari ulasan yang dibuat oleh peserta didik tersebut dapat dibaca dan dipahami kecenderungan sikap yang dimilikinya. Untuk menilai perubahan perilaku atau sikap peserta didik secara keseluruhan, khususnya kelompok mata pelajaran agama dan akhlak mulia, kewarganegaraan dan kepribadian, estetika, dan jasmani, semua catatan dapat dirangkum dengan menggunakan Lembar Pengamatan berikut ini.

\section{Penilaian Portofolio}

Penilaian portofolio pada dasarnya menilai karya-karya peserta didik secara individu pada satu periode untuk suatu mata pelajaran. Berdasarkan informasi perkembangan tersebut, guru dan peserta didik dapat menilai sendiri perkembangan kemampuan peserta didik dan

\section{Contoh Format Penilaian Sikap}

\begin{tabular}{|l|l|l|l|l|l|l|l|l|}
\hline No & Nama & Prilaku & Nilai & Bekerjasama & Berinisiatif & $\begin{array}{c}\text { Penuh } \\
\text { Perhatian }\end{array}$ & $\begin{array}{c}\text { Bekerja } \\
\text { Sistematis }\end{array}$ & Ket. \\
\hline & & & & & & & \\
\hline & & & & & & & \\
\hline
\end{tabular}

Catatan:

Kolom perilaku diisi dengan angka yang sesuai dengan kriteria: 1 = sangat kurang; 2 = kurang; 3 = sedang; 4 = baik; 5 = amat baik. Nilai merupakan jumlah dari skor-skor tiap indikator perilaku. Keterangan diisi dengan kriteria: Nilai 18-20 berarti amat baik; Nilai 14-17 berarti baik; Nilai 10-13 berarti sedang; Nilai 6-9 berarti kurang; Nilai 0-5 berarti sangat kurang. 
terus melakukan perbaikan. Dengan demikian, portofolio dapat memperlihatkan perkembangan kemajuan belajar peserta didik melalui karyanya, antara lain: karangan, puisi, surat, komposisi musik, gambar, foto, lukisan, resensi buku/literatur, laporan penelitian, sinopsis, dan sebagainya. Hal-hal yang perlu diperhatikan dan dijadikan pedoman dalam penggunaan penilaian portofolio di sekolah, antara lain:

a. Karya peserta didik adalah benar-benar karya peserta didik itu sendiri.

b. Saling percaya antara guru dan peserta didik dalam proses penilaian.

c. Kerahasiaan bersama antara guru dan peserta didik.

d. Milik bersama (joint ownership) antara peserta didik.

\subsection{Kompetensi, Kemampuan dan Komit- men Guru}

\subsubsection{Kompetensi Guru}

Kompetensi menurut Direktorat Pembinaan Sekolah Menengah Atas (Dalam Perangkat Penilaian KTSP, 2007:39), adalah kemampuan yang meliputi pengatahuan, ketrampilan, sikap dan nilai-nilai yang diwujudkan melalui kebiasaan berpikir dan bertindak. Setiap guru dituntut memiliki empat kompetensi, seperti diatur dalam
Peraturan Menteri Pendidikan Nasional No.16 tahun 2007 meliputi :

a. Kompetensi pedagogik ;

b. Kompetensi kepribadian ;

c. Kompetensi profesional; dan

d. Kompetensi sosial.

Kompetensi pedagogik terkait dengan kemampuan dan komitmen guru dalam merancang pembelajaran, melaksanakan pembelajaran, mengevaluasi, melaksanakan analisis hasil evaluasi serta melaksanakan program remidial dan pengayaan. Kompetensi meliputi ranah kognitif, psikomotor dan afektif. Dalam hal penyusunan penilaian, kognitifnya adalah pengetahuan tentang prosedur penyusunan penilaian, psikomotornya adalah ketrampilan menyusun penilaian, dan afektifnya adalah komitmen dalam menyusun penilaian.

\subsubsection{Kemampuan dan Komitmen Guru}

Model analisis mengenai situasi belajar mengajar yang dikemukakan disini adalah model analisis dari Gleackman (Dalam Sahertian \& Ida Aleida, 1981:41), yang disebut Paradigma Kategori Guru. Dalam model analisis tersebut, perkembangan guru dipandang dari dua segi yakni: kemampuan dan komitmen, yaitu berpikir abstrak/imajinatif dan keterlibatan aktif dalam

\section{CONTOH LEMBAR PENGAMATAN}

Mata Pelajaran

Perilaku/Sikap yang Diamati

Nama Peserta Didik

Kelas

Semester

Deskripsi Perilaku Awal

Deskripsi Perubahan Pencapaian :
: Pendidikan Agama Hindu

:

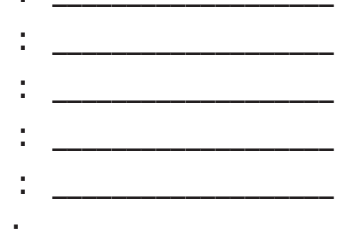

Pertemuan Hari/Tanggal

\begin{tabular}{|c|c|c|c|c|c|c|c|}
\hline No & Nama & ST & T & R & SR & Nilai & Ket. \\
\hline & & & & & & & \\
\hline & & & & & & & \\
\hline & & & & & & & \\
\hline
\end{tabular}

Keterangan:

a. Kolom capaian diisi dengan tanda centang sesuai perkembangan perilaku: $\mathrm{ST}=$ perubahan sangat tinggi $\mathrm{R}=$ perubahan $\operatorname{rendahT}=$ perubahan tinggi $\mathrm{SR}=$ perubahan sangat rendah

b. Informasi tentang deskripsi perilaku diperoleh dari pertanyaan langsung, laporan pribadi, dan buku catatan harian. 
tanggung jawab yang mendalam.

\section{1) Kemampuan Guru}

Menurut Sahertian \& Ida Aleida (1992:42), guru yang tingkat berpikirnya abstrak dan imajinatif yang tinggi, punya kemampuan untuk berdiri di depan kelas dan dengan mudah menghadapi masalah-masalah belajar mengajar seperti manajemen kelas, disiplin, menghadapi sikap acuh tak acuh dari siswa, dan mampu menentukan alternatif pemecahan masalah. Ia juga dapat merancang berbagai program belajar, dan dapat memimpin siswa dari berpikir nyata ke berpikir konseptual.

\section{2) Komitmen Guru}

Menurut Glickman (dalam Sahertian, 1994:44): yang dimaksud dengan komitmen adalah kecendrungan dalam diri seseorang untuk merasa terlibat aktif dengan penuh rasa tanggungjawab. Komitmen lebih luas dari kepedulian, sebab dalam pengertian komitmen tercakup arti "usaha dan dorongan serta waktu yang cukup banyak".

Konsekwensi dari komitmen ini, guru harus menyediakan waktu dan energi dalam melaksanakan tugasnya. Komitmen ini tidak diperoleh sejak lahir, tetapi harus dipelajari dan dikenal, bagaimana membentuk rasa cinta pada tugas sebagai guru. Seorang guru yang punya komitmen tinggi akan memiliki kepedulian terhadap tugas, kebutuhan siswa, teman sejawat atau atasan langsung. Ia punya komitmen terhadap tugas yang dibebankannya, termasuk tanggungjawab terhadap bangsa, negara dan sesama manusia.

Dari pengertian kompetensi yaitu kemampuan yang meliputi pengatahuan, ketrampilan, sikap dan nilai-nilai yang diwujudkan melalui kebiasaan berpikir dan bertindak, maka komitmen menyangkut aspek sikap dan nilai. Sikap merupakan suatu kecendrungan untuk bertindak secara suka atau tidak suka terhadap suatu objek dan Nilai merupakan suatu keyakinan terhadap perbuatan, tindakan, atau perilaku yang dianggap baik dan yang dianggap buruk.

\subsubsection{Pendapat Penulis}

Seorang guru yang profesional harus memiliki kompetensi lengkap yang meliputi pengeta- huan, ketrampilan dan sikap/prilaku.

- Pertama, dia harus mempunyai kemampuan kognitif, yaitu memiliki pengetahuan yang memadai baik pengetahuan tentang materi pelajaran maupun strategi atau model-model pembelajaran. Pengetahuan tentang strategi atau modelmodel pembelajaran, guru tak hanya mahir dengan strategi ekspositori tapi juga harus mampu melaksanakan pembelajaran dengan strategi diskoveri inkuiri.

- Kedua, dia juga harus memiliki kemampuan psikomotor atau ketrampilan. Baik ketrampilan dalam menyusun rencana pelaksanaan pembelajaran maupun ketrampilan untuk melaksanakannya. Dengan kata lain, dia harus dapat menulis apa yang akan dilakukan dan sebaliknya juga harus mampu melaksanakan apa yang telah ditulisnya.

- Ketiga, dia harus memiliki kemampuan afektif (sikap, minat, konsep diri, nilai dan moral) untuk mampu menjadi guru yang patut diteladani. Dia harus memiliki disiplin, etos kerja dan dedikasi yang tinggi untuk mencapai keberhasilan dalam melaksanakan kegiatan belajar mengajar.

Ketiga ranah kompetensi itu dapat dikelompokkan menjadi dua yaitu kemampuan dan komitmen. Kemampuan meliputi pengetahuan dan ketrampilan, komitmen meliputi dorongan, usaha dan penyediaan waktu yang cukup banyak. Keduanya sangat menentukan keberhasilan guru dalam melaksanakan tugas profesinya.

\subsection{Motivasi}

\subsubsection{Peranan Motivasi}

Ahmad Rohani (2004:12) mengatakan seorang individu akan terdorong melakukan sesuatu bila merasakan ada kebutuhan. Kebutuhan ini yang menimbulkan ketidakseimbangan, rasa ketegangan yang menuntut kepuasan supaya kembali pada keadaan keseimbangan (balancing). Sehubungan pentingnya motivasi untuk mencapai sukses dalam belajar, Sardiman (1994:98) mengatakan bahwa peranan motivasi belajar yang khas adalah dalam hal penumbuhan gairah, merasa senang dan semangat untuk belajar. 


\subsubsection{Pendapat Penulis}

Meningkatnya kemampuan guru-guru serta tumbuhnya komitmen guru-guru dalam membuat RPP Inovatif sangat tergantung dari seberapa besar motivasi yang dimilikinya. Motivasi itu dapat dirangsang oleh faktor dari luar (motivasi ekstrinsik) tetapi motivasi itu adalah tumbuh di dalam diri seseorang (motivasi instrinsik). Sebagai supervisor, seyogyanya memperhatikan prinsip-prinsip menumbuhkan motivasi antara lain : pemberian tantangan, keterlibatan harga diri, penghargaan, persaingan, kerjasama.

Sesuai dengan teori, kebutuhan manusia berjenjang. Dengan asumsi bahwa kebutuhan dasar seperti kebutuhan fisiologis, kebutuhan akan rasa aman, kebutuhan akan pengakuan, penerimaan dan kasih sayang telah terpenuhi, maka kebutuhan akan penguasaan ilmu pengetahuan, keberhasilan dan lain-lain merupakan suatu kesenjangan/ ketidakseimbangan. Kesenjangan itu, jika dikelola dengan baik oleh supervisor akan menimbulkan motivasi berprestasi yang kuat.

Setidaknya supervisor pada awalnya dapat menjadi motivator ekstrinsik sebelum tumbuhnya motivasi instrinsik pada guru-guru. Kunci keberhasilan adalah kemampuan supervisor membuat agar penyusunan instrumen penilaian menjadi kebutuhan guru.

\subsection{Andragogi}

\subsubsection{Konsep Andragogi}

Knowles dalam Piet Sahertian dan Purwoko (1996:22) menyatakan andragogi adalah ilmu dan seni membantu orang dewasa untuk dapat belajar efektif. Selanjutnya menurut Piet Sahertian dan Purwoko (1996:25) : Dalam proses mendidik orang dewasa, pematangan atau pengembangan yang bertujuan mengubah sifat tergantung (dependent) menjadi sifat tak tergantung (independent). Orang dewasa puas dengan hasil kerjanya sendiri, ia menuntut perlakuan dalam statusnya sebagai orang dewasa. Berdasarkan perubahan status itu, orang dewasa dalam proses belajar tidak senang bila ia diperlakukan, diarahkan sebagai anak.

\subsubsection{Penerapan Konsep Andragogi}

Piet Sahertian dan Purwoko (1996:27) menyatakan karena yang menjadi sumber belajar adalah diri orang dewasa itu sendiri, maka masalahnya bagaimana menggunakan teknik- teknik yang membuka jalan bagi orang dewasa agar belajar efektif itu perlu diupayakan kegiatan belajar sendiri, seperti : diskusi, menganalisis kasus, simulasi, permainan peran, praktek lapangan, latihan kerja, seminar dan lokakarya.

\subsection{Penerapan Kerja Praktek Pada Kegiatan KKG}

KKG (kelompok kerja guru) adalah wadah berkumpulnya guru-guru pada tingka pendidikan dasar (SD) yang berfungsi sebagai media koordinasi serta komunikasi terkait persamaan persepsi guna membahas berbagai permasalahan yang dihadapi dalam proses pembelajaran. Dengan demikian strategi kerja praktek dalam kregiatan KKG memilki peran yang sangat besar, sebab mengacu pada kerucut pengalaman belajar dari Peter Sheal, terlihat bahwa pengalaman belajar yang optimal akan dicapai, jika peserta belajar sampai pada tingkat melakukan dan mengatakan. Melakukan dalam hal ini adalah praktek penyusunan penilaian dan dilaksanakan dalam bentuk presentasi hasil kerja.

Ahmad Rohani (2004:6) mengatakanbelajar yang berhasil mesti melalui berbagai macam aktifitas, baik aktifitas fisik maupun psikis. Pakar Psikologi Pendidikan J. Peaget (dalam Ahmad Rohani, 2004:7) mengatakan seseorang berpikir sepanjang berbuat. Tanpa berbuat seseorang tidak akan berpikir. Agar ia berpikir sendiri (aktif) maka ia harus diberi kesempatan untuk berbuat sendiri.

Berdasarkan teori-terori tersebut, dan dikaitkan dengan konsep andragogi maka pembelajaran yang terkait dengan diskusi dan praktek harus dikedepankan dalam penelitian ini. Bulletin Kent Mathematics Project (1990:15) mengajukan tiga model pembelajaran yaitu discussion, investigation dan practice work.

Dalam Kamus Inggris-Indonesia (1984:442) arti kata "practice" adalah : 1) latihan, 2) praktek, 3) kebiasaan dan (1984:652) arti kata "work" adalah : 1) pekerjaan, 2) karya, 3) kerja. Dengan demikian practice work dapat diterjemahkan menjadi "Kerja Praktek".

\subsubsection{Pendapat Penulis}

Pemilihan strategi kerja praktek adalah implementasi konsep andragogi. Dengan membuat bentuk kegiatan sesuai selera orang dewasa, diharapkan tumbuh motivasi yang tinggi pada gu- 
ru-guru untuk membuat instrument penilaian sesuai dengan tuntutan kurikulum 2013. Walau motivasi yang tumbuh pada awal adalah motivasi ekstrinksik (karena dibina oleh pengawas akademis) tapi lama kelamaan diharapkan yang muncul adalah motivasi instrinsik (tumbuh dari dalam sebagai sebuah kebutuhan guru).

Kerja praktek akan memberikan pengalaman belajar yang optimal kepada guru-guru. Dalam kaitan ini, perlu dicamkan kembali kata-kata mutiara kuno: "saya mendengar maka saya lupa, saya melihat maka saya ingat, saya mengerjakan maka saya mengerti"

\subsection{Umpan Balik}

\subsubsection{Peranan Umpan Balik}

Umpan balik (feedback) adalah sebuah kegiatan untuk memberikan informasi balik kepada pembelajar tentang kemajuan hasil kerjanya. Menurut Arbono Lasmahadi (2005 : 1) : Salah satu komponen penting dalam proses belajar adalah adanya umpan balik (feedback). Berdasarkan Peraturan Menteri Pendidikan Nasional No.41 tahun 2007, dalam kegiatan konfirmasi guru : memberikan umpan balik positif dan penguatan dalam bantuk lisan, tulisan, isyarat maupun hadiah terhadap keberhasilan peserta didik.

\subsubsection{Pendapat Penulis}

Dalam penelitian ini digunakan dua cara pemberian umpan balik yaitu :

1) Bentuk tulisan: peneliti memberikan catatan-catatan singkat pada hasil kerja guru untuk menunjukkan hal-hal yang masih memerlukan perbaikan/penyempurnaan lebih lanjut. Kalimat-kalimat dalam umpan balik dapat berupa komentar, petunjuk maupun pertanyaan.

2) Bentuk lisan : peneliti melaksanakan tanya jawab dengan guru tentang kemajuan hasil kerjanya, yang dilaksanakan pada kegiatan presentasi hasil kerja dan juga pada kegiatan mandiri.

Umpan balik yang diberikan terhadap hasil kerja guru-guru diharapkan dapat menggugah dan meningkatkan motivasi guru-guru untuk mengkaji lebih dalam lagi petunjuk maupun pertanyaan-pertanyaan singkat pada umpan balik itu. Teknik Umpan Balik dalam penilaian Instrumen penilaian sesuai tuntutan kurikulum 2013, diharapkan dapat memberikan arah yang lebih terfokus untuk mempermudah guru-guru dalam melakukan perbaikan (revisi) instrumen penilaian tersebut.

\subsubsection{Kerangka Berpikir}

Kebiasaan lama "teacher centre oriented" telah mengakar pada guru. Akan sangat sulit mengubah menjadi "student centre oriented". Diperlukan komitmen dan kemampuan yang tinggi dari guru-guru. Komitmen dan kemampuan bukan bawaan sejak lahir, keduanya dapat ditingkatkan melalui proses pembelajaran dan pembiasaan. Berdasarkan teori motivasi, kemampuan seseorang dapat ditingkatkan dengan menumbuhkan motivasi berprestasi.

Motivasi akan tumbuh akibat adanya kebutuhan yang lebih tinggi, yaitu kebutuhan akan penguasaan ilmu pengetahuan, dan keberhasilan melaksanakan tugas. Sesuai dengan konsep andragogi, dan pendapat para akhli psikologi pendidikan, kemampuan/ ketrampilan guru dapat ditingkatkan dengan memberi kesempatan kepada guru untuk melaksanakan praktek, mempresentasikan hasil kerjanya dan mendapat umpan balik tentang hasil kerjanya.

\section{PENUTUP}

a. Membalik paradigma pendidikan dari paradigma pengajaran menjadi paradigma pembelajaran atau membalik dari "techer centre oriented" menjadi "student centre oriented" bukanlah hal mudah bagi guru. Kunci keberhasilan guru dalam menyusun Instrumen penilaian sesuai dengan standarisasi yang belaku terletak pada pada kemampuan guru memahami dan menggunakan model-model pembelajaran Inovatif.

b. Setiap proses pembelajaran (termasuk untuk orang dewasa) hendaknya memunculkan kompetensi secara utuh meliputi ranah kognitif, psikomotor dan afektif. Afektif, yang meliputi aspek sikap, minat, konsep diri, nilai dan moral, akan menunjang pencapaian kognitif dan psikomotor.

c. Minat berhubungan dengan dorongan atau motivasi. Dalam meningkatkan kemauan seseorang untuk berbuat, maka motivasi harus ditumbuhkan. Motivasi jangan sekedar ekstrinsik, tapi harus 
muncul motivasi instrinsik. Dorongan untuk memenuhi kebutuhan akan pengakuan dan penguasaan ilmu pengetahuan harus ditumbuh kembangkan.

d. Seseorang akan mau melaksanakan sesuatu yang baru yang bertentangan dengan kebiasan lama, apabila pola pikirnya telah berubah. Pola pikir seseorang akan berubah, jika telah memiliki pemahaman yang baik terhadap konsep yang baru tersebut. Jadi agar seseorang mau melaksanakan sesuatu yang baru, maka langkah pertama adalah memberi pemahaman yang benar.

e. Pemahaman seseorang akan mendekati sempurna jika kepadanya diberi kesempatan untuk melakukan praktek, dan mempresentasikan hasil kerjanya sendiri. Maka pola pembelajaran yang hanya mengedepankan ekspos faktor harus dihindarkan dan diperbanyak pola-pola kerja praktek.

f. Pemberian umpan balik sangat penting untuk mengarahkan pola pikir dalam pemecahan masalah dan sebagai petunjuk arahan kerja untuk mencapai hasil belajar yang optimal.

g. Model pembelajaran untuk orang dewasa (andragogi) hendaknya menjadi perhatian dan dilaksanakan dalam setiap kegiatan pembelajaran, karena orang dewasa tidak senang diperlakukan sebagai anak-anak.

\section{DAFTAR PUSTAKA}

Badan Standar Nasional Pendidikan. 2006. Panduan Penyusunan Kurikulum Tingkat Satuan Pendidikan. Jakarta : BSNP.

Bulletin Kent Mathematics Project (1990).

Depdikbud. 1992. Buku Pedoman Penyelenggaraan Musyawarah Guru Mata Pelajaran. Jakarta : Depdikbud.

1993. Dengan Pemantapan Kerja Guru Kita Siapkan Sumber Daya Manusia yang Berkualitas Untuk Menyongsong Pembangunan Jangka Panjang Tahap II. Jakarta : Depdikbud.

Depdiknas. 2003. Kurikulum Berbasis Kompetensi. Jakarta : Depdiknas. 2005. Peraturan Pemerintah Nomor 19 tahun 2005 tentang Standar Nasional Pendidikan. Jakarta : Depdiknas.

2007. Peraturan Menteri Pendidikan Nasional No. 16 tahun 2007 tentang Kualifikasi Akademik dan Kompetensi Guru. Jakarta : Depdiknas.

2007. Peraturan Menteri Pendidikan Nasional No.41 tahun 2007 Tentang Standar Proses Pendidikan Dasar dan Menengah. Jakarta : Depdiknas.

Dirjen Pendidikan Tinggi. 2007. Panduan Penyusunan Perangkat Portofolio Sertifikasi Guru Dalam Jabatan. Jakarta : Depdiknas.

Direktorat Dikmenum. 1999. Manajemen Peningkatan Mutu Berbasis Sekolah. Jakarta : Depdiknas. 